\title{
The study of the suitability for use in agriculture of sludge and hydrochemical indicators of water in the reservoirs of the fish farm LLC "Albashi"
}

\author{
Natalya Yurina $^{1,2, *}$, Denis Yurin ${ }^{1}$, Irina Astakhova ${ }^{3}$, Tatyana Shcherbatova ${ }^{4}$ and Igor \\ Shcherbatov ${ }^{4}$ \\ ${ }^{1}$ Krasnodar Research Centre for Animal Husbandry and Veterinary Medicine, 4, Pervomaiskaya Str., \\ Znamensky village, Krasnodar, 350055, Russia \\ ${ }^{2}$ Kuban State Agrarian University named after I.T. Trubilin, 13, Kalinina Str., Krasnodar, 350000, \\ Russia \\ ${ }^{3}$ Maikop State Technological University, 191, Pervomayskaya Str., Maykop, Republic of Adygeya, \\ 385000, Russia \\ ${ }^{4}$ Branch of Maikop State Technological University in the village of Yablonovsky, Republic of \\ Adygeya, 385140, Russia
}

\begin{abstract}
The study of suitability for the use in agriculture of sludge deposits and hydrochemical indices of water bodies of fish-growing enterprise of LLC "Albashi" were carried out. It is an enterprise engaged in breeding and growing pond fish and sturgeon in pools and gardens, crayfish, growing aquapon greens. Fresh water bodies of reservoir type LLC "Albashi" contain a large number of bottom deposits. The layer of sludge deposits on the bottom in places reaches the power of 2-5 meters, and the underground power is difficult. Bottom sediments were taken from a depth of 1.0-1.2 m from the surface. The hydrochemical regime of the studied water bodies fully corresponds to the cultivation of aquaculture objects and hydroponic plants. Sufficient suspended matter in water $(8.2$ $\left.\mathrm{mg} / \mathrm{dm}^{3}\right)$. The complete absence of dichlorodiphenyl trichloroethane, its metabolites and pesticides characterizes the products produced as environmentally safe. Consequently, bottom sediment site under study can be considered suitable for agricultural production.
\end{abstract}

\section{Introduction}

Eutrophication of water bodies has become one of the most serious threats to aquatic ecosystems in the world, especially water quality, and can further have a negative impact on people's health. Combining factors of climate change and human activity, eutrophication has expanded from small lakes in the temperature zone to water lakes in cold regions (called cold water lakes) [1-4].

Due to natural eutrophication of lakes and rivers, as well as anthropological activity, a large number of sludge deposits appear, water reservoirs decompose and turn into marshes [5-8]. There are many ways to reduce the silting of lakes and rivers - to carry out

*Corresponding author: naden8277@ mail.ru 
mechanical cleaning. However, there is currently a problem of recycling sapropels and river silt. Therefore, the use of bottom sediments for fodder or agricultural purposes is a very relevant topic [9-12].

Most of the dams on the steppe rivers were built without projects, in the form of simple protection of the mounds with earthen fills, as a result of which the speed of water flow in them fell, the silting of the bottom began.

Currently, the sludge layer at the bottom reaches a power of 5 meters in places, and the underground power supply is completely stopped. Silting reduces the depth of steppe rivers, promotes their germination by aquatic vegetation. In many areas of these rivers, the areas occupied by cane, stump, and horgosis sprouts exceed $80 \%$ of their water surface.

As steppe rivers run mostly in densely populated terrain, their waters are actively used for irrigation, recreation, water supply and water disposal.

The general intensification of the intensity of bottom sediments leads to the growth and regulation of steppe rivers of the Krasnodar Region, which causes serious damage to the economy of the region. During recent decades, the rivers of the region have been under increasing pressure. In the historical past they were right bank sleeves of the relict delta of the Kuban River. During the natural transformation of the delta, these rivers gradually lost their connection to the main watercourse. The separation of sleeves from the indigenous channel of the Kuban River turned them into typical rivers of rain and snow food. Therefore, in the late 19th and early 20th centuries, the local population began to organize dams at separate points in the mounds of steppe rivers to accumulate water in ponds. This process was most developed in the last decades of the twentieth century. At present, all steppe rivers are divided into many separate water bodies (small reservoirs), and there is practically no single water stream from the upper current to the mouth in them [13-15].

\section{Materials and methods}

The purpose of the research was to study the suitability for use in agriculture of bottom sediments (fertilizers, feed additives) and hydrochemical indicators of water in fisheries of LLC "Albashi" in order to reduce the consequences of eutrophication of the water body and to obtain additional profits (cultivation of aquaculture and hydroponic greens).

To achieve the goal, the following objectives have been set and achieved:

1. Determine pesticide content in bottom sediments;

2. Study hydrochemical parameters of the water basin;

3. Identify the cross profile of the bottom of the water basin to calculate the amount of excavation.

The farm of LLC "Albashi" includes two channel ponds (the total area is 35 hectares). The average depth of the ponds on the water is 1.3-1.8 meters, the maximum depth is up to 3 meters. The ponds are divided by earth dams. Each dam has facilities to pass household and flood expenses along the Albashi River. The length of the Albashi River bed is $64 \mathrm{~km}$ and its basin is $895 \mathrm{~km}^{2}$. There are 43 dams.

Climatic conditions have a significant impact on the general salinity of water. Depending on the amount of atmospheric precipitation, the mineralization of water may vary in different ways. As a result of heavy atmospheric precipitation or intense melting of snow, mineralization decreases, and as water inflow decreases and the proportion of ground food increases, mineralization increases. The hydrochemical regime of the river is optimally suitable for breeding and containing different species of fish.

LLC "Albashi" is an enterprise engaged in breeding and growing pond fish and sturgeon in pools and gardens, crayfish, growing aquapon greens.

Ichtioplankton in the ponds of LLC "Albashi" is represented by the following species of fish: white amur, white fat, sazan or common carp. In order to restore the natural 
ichthyofauna of the water basin and create a press of predators, sudak and pike are planted in the water basin. As fodder predatory species of fish use weed fish. In order to feed predatory species of fish and to grow them faster each year, silver caraway is introduced into ponds.

Pools and gardens on the territory of LLC "Albashi" contain sturgeon fish: bester, russian sturgeon, russian-lensky sturgeon.

Water bodies on the Albashi River are typical channel ponds, descent ponds, with dependent water supply. In order to increase the fish productivity of water bodies, directed formation of ichthyofauna is recommended at the expense of valuable fish species: sazan (carp), white and motley silver carp, white amur. As biological meliorators it is recommended to plant sudak, pike, catfish. Crucian fish stocked in a pond is intended to feed predators.

Average daily temperature conditions (as a result of daily thermometer measurements) in 2019 under the conditions of LLC "Albashi" were the following: January: 0,3 ${ }^{\circ} \mathrm{C}$; February: $0,4{ }^{\circ} \mathrm{C}$; March: $4,9{ }^{\circ} \mathrm{C}$; April: $10,2{ }^{\circ} \mathrm{C}$; May: $17,4{ }^{\circ} \mathrm{C}$; June: $21,2{ }^{\circ} \mathrm{C}$; July: 23,1 ${ }^{\circ} \mathrm{C}$; August: $23,2{ }^{\circ} \mathrm{C}$; September: $17,4{ }^{\circ} \mathrm{C}$; October: $12,1{ }^{\circ} \mathrm{C}$; November: $5,2{ }^{\circ} \mathrm{C}$; December: $0,5^{\circ} \mathrm{C}$.

Fresh water bodies of reservoir type LLC "Albashi" contain a large number of bottom deposits. In the case of insufficient slurries in water containing the necessary nutrients for cultivated plants, it is always possible to compensate them by redistributing layers of water from the bottom of the water body enriched with slurries to the level of the developed plant for growing plants without soil.

At present, the Albashi River is divided into many separate water bodies (small reservoirs), and there is practically no single watercourse from the upper current to the mouth in them. The layer of sludge deposits on the bottom in some places reaches a power of 2-5 meters, and underground power is difficult.

Samples of lake sludge (the lake with artificial origin of Elizavetinskaya village in the Krasnodar Region with an area of 7 hectares) were selected for laboratory research as a positive control, as a standing water basin and extraction of quality sapropel for the production of fertilizers for plants and feed additives for animals, and a section of regulated runoff (experimental water basin) at a distance from 54.0 to $58.5 \mathrm{~km}$. from the mouth of the Albashi River of Leningradskij district of the Krasnodar Region.

Bottom sediments for analysis were collected from the control points by the envelope method, combining them into a laboratory sample. Bottom sediments were taken from the depth of 1.0-1.2 meters from the surface.

Studies of pesticide content in bottom sediments were carried out in the "Leningradskij district Veterinary Department" in accordance with the requirements of GS 1.2.3539-18 Hygienic standards of pesticide content in environmental objects, extraction of samples from fish and household water bodies from hydrochemical research methods (ed. 20.10.1983).

GHTsG (a - $\beta$-, $\gamma$-isomers) determined according to MU 2142-80 - Methodical instructions by searching of organochlorine pesticides in water, food, sterns and tobacco products by a chromatography method in a thin layer. 2,4-D acid, its salts and esters according to MU 1541-76 - Chromatographic methods for determining residual amounts of 2,4-dichlorophenoxyacetic (2,4-D) in water, soil, furage, plant and animal food. DDT and its metabolites - MU 2142-80 - Methodical instructions for the determination of organochlorine pesticides in water, food, feed and tobacco products by thin layer chromatography.

Hydrochemical indices were determined according to the extracts from hydrochemical studies of samples from the fisheries (ed. 20.10.1983), GOST 18164-72 - Drinking water. Dry residue determination method. Methodical instructions for sanitary assessment of water 
used in carpal fish farming by determination of biochemical oxygen consumption for five days (biochemical oxygen consumption 5) (ed. March 5, 1979).

A transverse bottom profile is necessary to calculate the volume of earthworks, to identify bottom relief data, and to solve various engineering problems.

Cross profile data were obtained by leveling points to the right and left of the main line, perpendicular to it, or at some arbitrary angle. In the processed leveling log, two cross bars are specified: on the oxygen consumption 6 and oxygen consumption 14 . A horizontal and vertical 1:200 cross profile on millimeter paper was drawn from the calculated cross profile point elevations.

\section{Results}

According to GOST R 54000-2010, sapropel of class 1, for use in agricultural production, should contain: (not more than $\mathrm{mg} / \mathrm{kg}$ ): cadmium 3, zinc - 300, lead - 50, copper - 100, mercury - 1.0, manganese - 500, cobalt - 20. No information of heavy metals above maximum allowable levels was found in the sample under study. Consequently, the bottom sediments studied refer to bottom sediments of class 1 suitability in agricultural production.

According to physical and chemical indicators, these bottom deposits can be classified as organo-limestone. The content of particles in samples exceeding $10 \mathrm{~mm}$ did not exceed $20 \%$, the content of ballast mechanical inclusions - did not exceed $1.0 \%$, acidity of salt extract $\mathrm{pH}-6.1$.

No pathogenic bacteria were found in the sample, including intestinal stick, enterococcus, staphylococcus, clostridium, and viable eggs and helminth larvae.

During the study of sludge sample from the waters of LLC "Albashi" the following results were obtained (Table 1).

Table 1. Results of the study of bottom sediments sample in ponds of LLC "Albashi".

\begin{tabular}{|c|c|c|c|c|}
\hline № & Name of indicator & $\begin{array}{c}\text { Unit of } \\
\text { measure }\end{array}$ & Test Result & Standard \\
\hline \multicolumn{5}{|c|}{ Pesticides } \\
\hline 1 & $\begin{array}{c}\text { GHTsG }(\mathrm{a}-\beta-, \gamma- \\
\text { isomers) }\end{array}$ & $\mathrm{mg} / \mathrm{kg}$ & $\begin{array}{c}(\mathrm{a}-\beta-, \gamma \text {-isomers) - are not found } \\
\text { (less than } 0.06)\end{array}$ & not more than 0.1 \\
\hline \multicolumn{5}{|c|}{ Safety indicators } \\
\hline 2 & $\begin{array}{c}2,4-D \text { acid, its salts } \\
\text { and esters }\end{array}$ & $\mathrm{mg} / \mathrm{kg}$ & not found & not more than 0.1 \\
\hline 3 & $\begin{array}{c}\text { DDT and its } \\
\text { metabolites }\end{array}$ & $\mathrm{mg} / \mathrm{kg}$ & not found (less than 0.06) & not more than 0.1 \\
\hline
\end{tabular}

During the research of the test of silt on safety indicators from an experimental reservoir of LLC "Albashi" it is established that GHTsG (a - $\beta$-, $\gamma$-isomers), 2.4-D acid, its salts and air, DDT and its metabolites in the studied sample are not found.

Consequently, the bottom deposits of the fresh water basin of LLC "Albashi" are quite suitable in their chemical composition for the use in agriculture.

As a result of the study of a sample of pond water in ponds of LLC "Albashi," it was revealed that nitrates and nitrites are present within the limits of permissible norms. Ammonia content is less than $0.04 \mathrm{mg}(\mathrm{N}) / \mathrm{dm}^{3}$, which does not exceed maximum permissible concentration (Table 2).

While measuring the hydrogen index, it was found that the reaction of the medium was slightly alkaline, within the permissible numbers. 
Table 2. Results of the study of the pond water sample in the ponds of LLC "Albashi".

\begin{tabular}{|c|c|c|c|c|}
\hline № & Name of indicator & $\begin{array}{l}\text { Unit of } \\
\text { measure }\end{array}$ & Tests results & Standard \\
\hline \multicolumn{5}{|c|}{ Nitrates and nitrites } \\
\hline 1 & Nitrates & $\mathrm{mg}(\mathrm{N}) / \mathrm{dm}^{3}$ & less than 0.02 & not more than 2.0 \\
\hline 2 & Nitrites & $\mathrm{mg}(\mathrm{N}) / \mathrm{dm}^{3}$ & less than 0.0003 & not more than 0.02 \\
\hline \multicolumn{5}{|c|}{ Quality indicators } \\
\hline 3 & Ammonia & $\mathrm{mg}(\mathrm{N}) / \mathrm{dm}^{3}$ & less than 0.04 & not more than 0.5 \\
\hline 4 & Hydrogen index $(\mathrm{pH})$ & unit $\mathrm{pH}$ & 7.2 & $6.8-8.5$ \\
\hline \multicolumn{5}{|c|}{ Water quality indicators } \\
\hline 5 & $\begin{array}{l}\text { Biochemical oxygen } \\
\text { consumption-5 }\end{array}$ & $\mathrm{mg}\left(\mathrm{O}_{2}\right) / \mathrm{dm}^{3}$ & 1.3 & not more than 3.0 \\
\hline 6 & Suspended substances & $\mathrm{mg} / \mathrm{dm}^{3}$ & 8.2 & not more than 25.0 \\
\hline 7 & Total iron & $\mathrm{mg} / \mathrm{dm}^{3}$ & less than 0.1 & not more than 1.8 \\
\hline 8 & Dissolved oxygen & $\mathrm{mg} / \mathrm{dm}^{3}$ & 10.4 & not less than 6.0 \\
\hline 9 & Sulfates & $\mathrm{mg} / \mathrm{dm}^{3}$ & less than 20.0 & not more than 100 \\
\hline 10 & Phosphates & $\mathrm{mg}(\mathrm{P}) / \mathrm{dm}$ & 0.008 & not more than 0.5 \\
\hline 11 & Chlorides & $\mathrm{mg} / \mathrm{dm}^{3}$ & 152.4 & not more than 300 \\
\hline
\end{tabular}

Biological oxygen consumption (BOC5) is $1.3 \mathrm{mg}\left(\mathrm{O}_{2}\right) / \mathrm{dm}^{3}$, which does not exceed the established standards, which indicates that the amount of easily oxidizing organic pollutants in water is within the permissible limits.

The amount of oxygen dissolved in water is $10.4 \mathrm{mg} / \mathrm{dm}^{3}$, which corresponds to the standards for fisheries.

Content of suspended substances, total iron, sulphates, phosphates, chlorides does not exceed the established norms.

Fresh water in reservoir types contains a large number of sapropel deposits of different chemical composition. In the case of insufficient slurries in water containing the necessary nutrients for cultivated plants, it is always possible to compensate them by redistributing layers of water from the bottom enriched with slurries to the level of the developed plant for growing plants without soil.

The hydrogen indicator $(\mathrm{pH})$, as measured periodically by $\mathrm{pH}$-meter Expert $\mathrm{pH}(3 \mathrm{x} 1)$, was $7,2 \pm 0.02$.

The results of measurements of bottom sediments capacity of fodder additive and fertilizer for agricultural production are presented in Table 3.

Table 3. Results of measurements of bottom sediments capacity suitable for use as a base of feed additive and fertilizer.

\begin{tabular}{|c|c|c|c|}
\hline Point numbers & Distances. $\mathbf{m}$ & $\begin{array}{c}\text { Bottom sediments } \\
\text { layer capacity. } \mathbf{~ m}\end{array}$ & $\begin{array}{c}\text { Layer volume } \\
\text { average). } \mathbf{~ m}^{\mathbf{3}} \text { per 200 } \\
\mathbf{m}^{\mathbf{2}} \text { area }\end{array}$ \\
\hline 1 & 200 & 0.00 & 0.00 \\
\hline 2 & 200 & 0.03 & 6.00 \\
\hline 3 & 200 & 0.10 & 20.00 \\
\hline 4 & 200 & 0.80 & 160.00 \\
\hline 5 & 200 & 0.80 & 160.00 \\
\hline 6 & 200 & 0.75 & 150.00 \\
\hline 7 & 200 & 0.75 & 150.00 \\
\hline 8 & 200 & 0.75 & 150.00 \\
\hline 9 & 200 & 0.95 & 190.00 \\
\hline 10 & 200 & 1.10 & 220.00 \\
\hline 11 & 200 & 1.00 & 200.00 \\
\hline 12 & 200 & 0.65 & 130.00 \\
\hline
\end{tabular}




\begin{tabular}{|c|c|c|c|}
\hline 13 & 200 & 0.70 & 140.00 \\
\hline 14 & 200 & 1.30 & 260.00 \\
\hline 15 & 200 & 1.25 & 250.00 \\
\hline 16 & 200 & 0.90 & 180.00 \\
\hline 17 & 200 & 0.90 & 180.00 \\
\hline 18 & 200 & 0.65 & 130.00 \\
\hline 19 & 200 & 0.25 & 50.00 \\
\hline 20 & 200 & 0.10 & 20.00 \\
\hline TOTAL & - & - & 2770 \\
\hline
\end{tabular}

\section{Conclusions}

Therefore, the volume of the selected soil along the measurement route is $2770 \mathrm{~m}^{3}$. For the whole body of water this indicator will be about 20 million $\mathrm{m}^{3}$.

Hydrochemical regime of the water reservoirs of LLC "Albashi" fully corresponds to cultivation of aquaculture objects and hydroponic plants. The water contains sufficient suspended matter $\left(8.2 \mathrm{mg} / \mathrm{dm}^{3}\right)$. The complete absence of dichlorodiphenyl trichloroethane, its metabolites and pesticides characterizes the products produced as environmentally safe. Consequently, bottom sediment on the Albashi River site under study can be considered suitable for agricultural production.

\section{Financing source}

The research was carried out within the framework of the grant of the President of the Russian Federation for the state support of young Russian scientists on the topic: "A new method of self-optimization of the use of the water surface of internal fresh water bodies in the cultivation of plants without soil" MD-1886.2019.11.

\section{References}

1. Z. Yu, J. Amdahl, D. Kristiansen, P. Takle Bore, Ocean Engineering 194, 106653 (2019) doi:10.1016/j.oceaneng.2019.106653

2. S. Boxman, M. Nystrom, S.J. Ergas Show, M.A. Trotz, K.L. Main, Ecological Engineering 120, 299-310 (2018) doi: 10.1016/j.ecoleng.2018.06.003

3. M. Kõiv, K. Mahadeoa, S. Brienta, D. Claveau-Mallet, Y. Comeau, Ecological Engineering 94, 190-199 (2016) doi: 10.1016/j.ecoleng.2016.05.060

4. J. Puigagut, H. Angles, F. Chazarenc, Y. Comeau, Aquaculture 318, 7-14 (2011) doi: 10.1016/j.aquaculture.2011.04.025

5. M. Ayub Hossain, A. Kumar Sarker, M. Nurul Amin, M. Mokarrom Hossain, M. sumon Miah, Aquacultural Engineering 74, 62-69 (2016) doi: 10.1016/j.aquaeng.2016.06.001

6. V. Gagnon, F. Chazarenc, M. Kõiv, J. Brisson, Water Research 46, 5305-5315 (2012) doi: 10.1016/j.watres.2012.07.007

7. V. Gagnon, F. Chazarenc, Y. Comeauc, J. Brisson, Ecological Engineering 61, 593600 (2013) doi: 10.1016/j.ecoleng.2013.02.017

8. C.I.A. Ferreira, V. Calisto, M. Otero, H. Nadais, Aquacultural Engineering 74, 76-83 (2016) doi: 10.1016/j.aquaeng.2016.06.003 
9. M. Harnisz, E. Korzeniewska, I. Gołaś, Chemosphere 128, 134-141 (2015) doi: 10.1016/j.chemosphere.2015.01.035

10. R. Lunda, K. Roy, J. Másílko, J. Mráz, Journal of Environmental Management 245, 255-263 (2019) doi: 10.1016/j.jenvman.2019.05.130

11. T. Aruety, T. Brunner, Z. Ronen, A. Gross et al., Aquaculture 450, 335-341 (2016) doi: 10.1016/j.aquaculture.2015.08.002

12. N. Yurina, A. Koshchaev, D. Osepchuk, E. Maksim, A. Danilova, D. Shumeiko, International Journal of Engineering and Advanced Technology 9, 4957-4960 (2019) doi: 10.35940/ijeat.A2109.109119

13. V. Krymov, D. Yurin, S. Kononenko, E. Maxim, N. Yurina, International Journal of Pharmaceutical Research 10, 316-322 (2018) doi: 10.31838/ijpr/2018.10.04.029

14. N. Labutina, D. Osepchuk, D. Yurin, N. Yurina, B. Khorin, D. Kulova, Amazoniainvestiga 8, 668-673 (2019) https://amazoniainvestiga.info/index.php/amazonia/ article/view/206

15. N. Yurina, D. Yurin, E. Maxim, A. Danilova, I. Tletseruk, Amazonia Investiga 9, 279284 (2020) https://amazoniainvestiga.info/index.php/amazonia/article/view/1067 